Acta vet. scand. $1974,15,461-486$.

From the Department of Medicine I and the Department of Pathology, Royal Veterinary College, Stockholm, Sweden.

\title{
TOXICITY OF HALOGENATED OXYQUINOLINES IN DOGS. A CLINICAL STUDY
}

V. PATHOLOGICAL FINDINGS *

\author{
By \\ Birgitta Lannek and Lennart Jönsson
}

\begin{abstract}
LANNEK, BIRGITTA and LENNART JÖNSSON: Toxicity of halogenated oxyquinolines in dogs. A clinical study. V. Pathological findings. Acta vet. scand. 1974, 15, 461-486. - A description is given of the post-mortem findings in 21 cases of acute spontaneous oxyquinoline poisoning in dogs after administration of halogenated oxyquinoline drugs once or over a short period. The findings are in accordance with the results of necropsy of 7 cases of experimentally induced oxyquinoline poisoning. Biopsy specimens of the liver were taken in 18 dogs. The investigation reveals that spontaneous as well as experimental poisonings give rise to severe myocardial and liver injuries. The myocardial lesions consisted of focal necrosis with interstitial cellular reaction. The areas of necrosis were most frequent in the papillary muscles of the left ventricle. The liver-cell damage ranged from cloudy swelling to hydropic degeneration with depositions of lipids. In 3 experimental cases, in which rapid fixation methods were used, it was possible to evaluate the pathological lesions in the neurons of the brain and spinal cord. Degenerative neuronal changes with chromatolysis and vacuolation were observed, especially in the hippocampus and hypothalamus. It was presumed that the injuries and destruction of these structures had caused symptoms that were consistent with the clinical pictures of the dogs. The clinical symptoms and post-mortem changes were believed to be due to a toxic effect on the myocardium, liver, and central nervous system.
\end{abstract}

dogs; oxyquinolines; convulsions; liver injury; myocardial injury; neuronal degeneration;

hippocampus; hypothalamus.

The literature on spontaneous and experimental poisoning in dogs with halogenated oxyquinoline is sparse. Only a few works with clinical and post-mortem examination are presented (Hangartner 1965, Schantz \& Wikström 1965, Müller 1967,

*) Supported by grants from the Swedish Medical Research Council. 
Püschner \& Fankhauser 1969, Tateishi et al. 1971). The clinical symptoms described in these works appeared mostly within 12 hrs. after the dogs were given an oxyquinoline drug. The symptoms were characterized by apathy or excitation and nervousness, aggressiveness, tremor, convulsions, and salivation. Clinical examination revealed myocardial and liver injuries and the outcome was sometimes fatal.

Hangartner necropsied 5 dogs and found encephalomalacia, myocardosis, hepatosis, and nephrosis or nephritis. In a necropsy material of 6 dogs, Schantz \& Wikström demonstrated focal myocarditis and liver-cell degeneration. At necropsy of $1 \mathrm{dog}$, Müller found hyperaemia in the brain and leptomeninges and haemorrhages in kidneys and brain, especially in the brain stem. Nothing was mentioned about liver or myocardial damage. Püschner \& Fankhauser described the clinical symptoms and the morphological picture of experimental oxyquinoline poisoning in mice, but the number of animals was not published. They pointed out that in spite of serious symptoms of poisoning, little is found at post-mortem examination. The nerve cells revealed pycnotic nuclei in various parts of the brain but especially frequent in the cornu ammonis. In an experimental study of clioquinol (vioform) in 20 dogs, Tateishi et al. provoked acute and chronic poisoning in 17 dogs. In the chronic cases, they used a dosage of $60-144$ $\mathrm{mg}$ of clioquinol per $\mathrm{kg}$ body weight and day. They described clinical symptoms and morphological changes similar to those seen in the subacute myelo-optic neuropathy (S.M.O.N.) syndrome in man. Degenerative changes were found in the nervous system, the severity of which depended on the duration of symptoms. Sandoz AG in Switzerland kindly provided results of toxicity studies on Intestopan (broxyquinoline) in dogs (Griffith 1969, unpublished). Hepatic lesions were observed at all dose levels used (100, 200, $400 \mathrm{mg}$ per $\mathrm{kg}$ body weight) and $1 \mathrm{dog}$ died. Swollen cells, areas of necrosis and fat deposits were observed in the liver. The kidneys revealed inflammatory infiltrates and fat droplets and pigments in the tubuli cells.

Little attention seems to have been paid to the morphological picture of acute oxyquinoline poisoning in dogs. The object of the present work was therefore to study the pathological changes in acute and experimental oxyquinoline poisoning after administration of the drug once or over a short period. 


\section{SPONTANEOUS CASES}

One of us (B.L.) has in previous works (Lannek 1973, 1974) described the case histories, clinical pictures, and laboratory findings in 100 cases of poisoning due to treatment with drugs containing halogenated oxyquinolines. This material consisted of 100 dogs and included that of Schantz \& Wikström. The mortality was $30 \%$ (spontaneous death in $19 \%$ and euthanasia in $11 \%$ ), and of the dogs that survived the acute poisoning 6 were killed later because of lasting symptoms. It was then shown that there was no breed or sex disposition, but old dogs were affected more often than young dogs and showed higher mortality. The dosage varied between 6.9 and $250 \mathrm{mg}$ per $\mathrm{kg}$ body weight, the mean value being $58.98 \pm 46.60 \mathrm{mg}$. Necropsy was performed in $21 \mathrm{dogs}$ out of 30 ; in 9 cases necropsy was refused by the owners.

The clinical examination of spontaneous cases often revealed liver and myocardial injuries. Thus there were increased serum enzymes (SASAT, SALAT, and SOCT) and electrocardiographic changes (Lannek 1974).

Liver-biopsy specimens were taken in 18 out of 100 cases. Biopsy was not performed in the majority of cases, either because the dog did not keep still enough for successful sampling (hyperactivity or tremor), or the procedure was considered to be too risky in view of the dog's condition. Necropsy was performed in 4 of the 18 cases.

\section{Methods}

All the dogs (21) in the present investigation were subjected to complete necropsy. Sections for microscopical examination were taken from several organs and always from liver and kidneys. With 1 exception, the hearts were also examined microscopically.

The tissue specimens were fixed in $10 \%$ neutral formalin. Frozen sections were stained with Scharlach R. Paraffin-embedded sections were stained routinely with haematoxylin-eosin, and van Gieson's picrofuchsin-haematoxylin. To identify early changes in the myocardium, the following staining methods were used: Mallory's phosphotungstic acid haematoxylin (PTAH), acid fuchsin (Poley et al. 1964), Masson's trichrome, and Goldner's modification of that stain.

Liver-biopsy specimens were taken in 18 cases with Menghi- 
nis' liver-biopsy needle (Lannek 1968). The specimens were fixed in $10 \%$ neutral formalin solution. The fixed specimens were cut on a freezing-microtome and stained with Scharlach R. Parts of some specimens were embedded in paraffin, sectioned, and stained with haematoxylin-eosin.

\section{Results}

Data on the n ecropsy cas es concerning breed, age, sex, oxyquinoline dose, most significant clinical symptoms (at home and at the clinic), laboratory findings and post-mortem findings are summarized in Table 1 . The case numbers refer to Table 1 in an earlier work (Lannek 1974), where dala concerning signalment and case histories are recorded.

Diffuse fat deposition in the liver and/or in Kupffer cells was observed in 15 out of 18 liver-biopsy specimens, and circulatory changes (acute congestion) in 6. One specimen showed acute hepatitis. Degenerative or necrotic changes were, generally, not present in specimens from early stages but developed in 4 cases after a few days when new specimens were taken.

Poisoning with oxyquinolines resulted in severe myocardial lesions in almost all the dogs. Signs of myocardial damage were seen macroscopically in 16 cases. Coarse tigroid pale foci were observed in 9 hearts. The foci varied in size, from a few $\mathrm{mm}$ up to $10 \mathrm{~mm}$ in diameter. They were localized in all areas of the left and right ventricles but were most frequent in the papillary muscles of the left ventricle. Subendocardial, subepicardial, and intramural haemorrhages were demonstrated in 10 cases. The subendocardial haemorrhages were most marked in the papillary muscles and the trabeculae carneae.

Secondary to the myocardial damage, circulatory disturbances were observed in several organs. The lungs, liver, kidneys, brain, and meninges were often congested. Acute bronchopneumonia was noted in 2 and chronic nephritis in 4 cases. Acute gastric erosions and ulcerations were found in the fundus region in 6 cases.

\section{Microscopical findings}

Various stages of myocardial degeneration and necrosis were noted in 19 cases. Subendocardial and intramural haemorrhages 


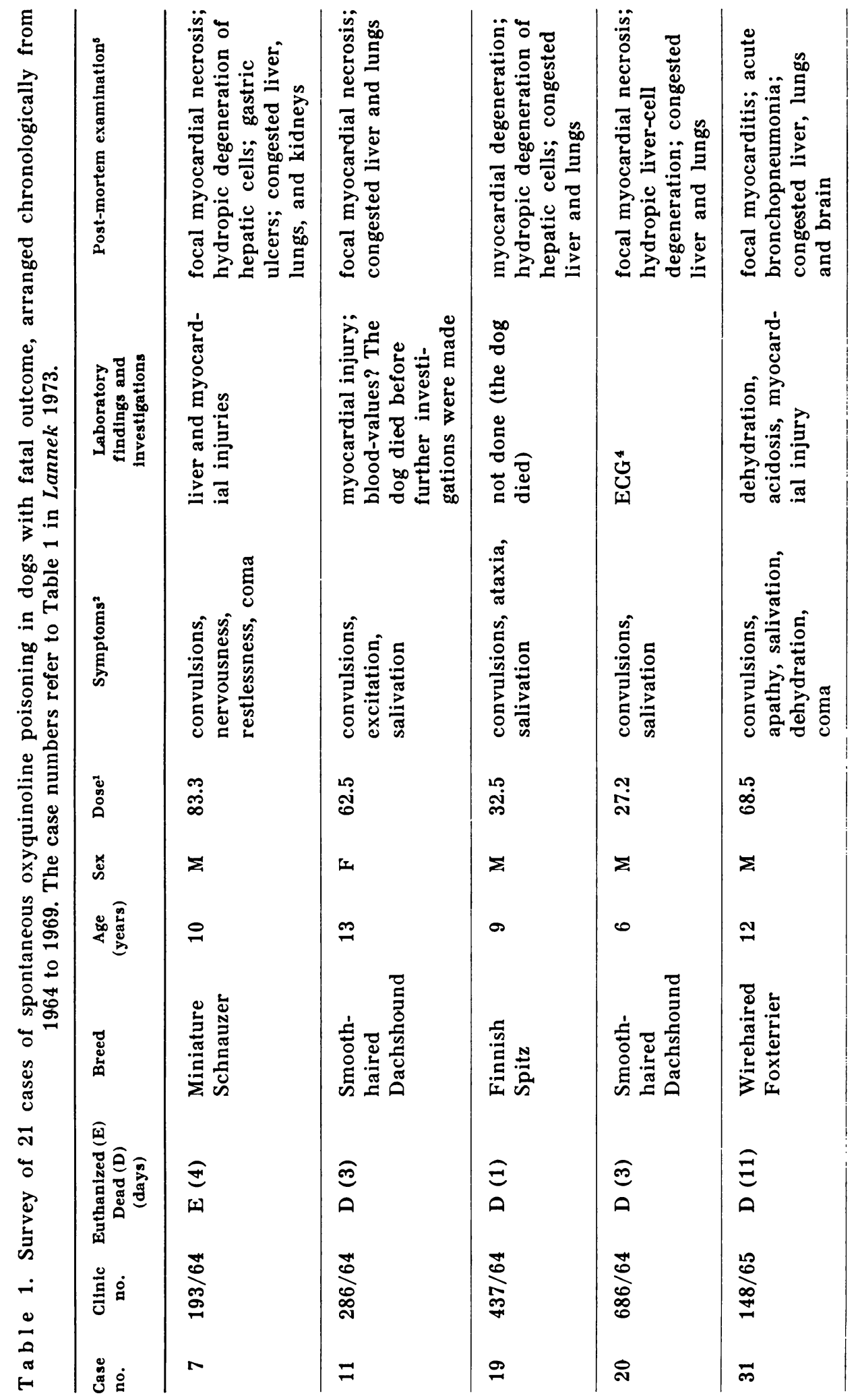




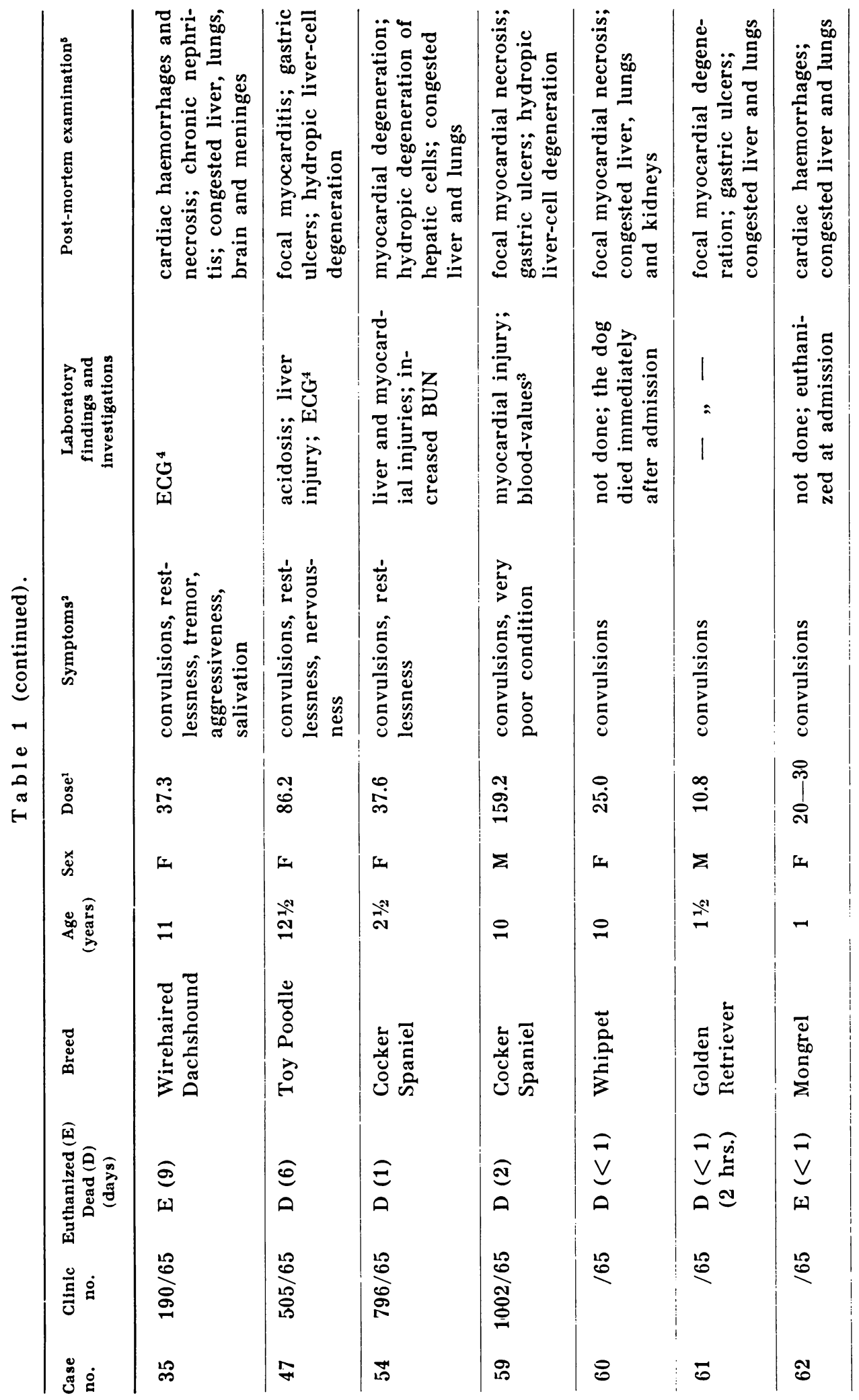




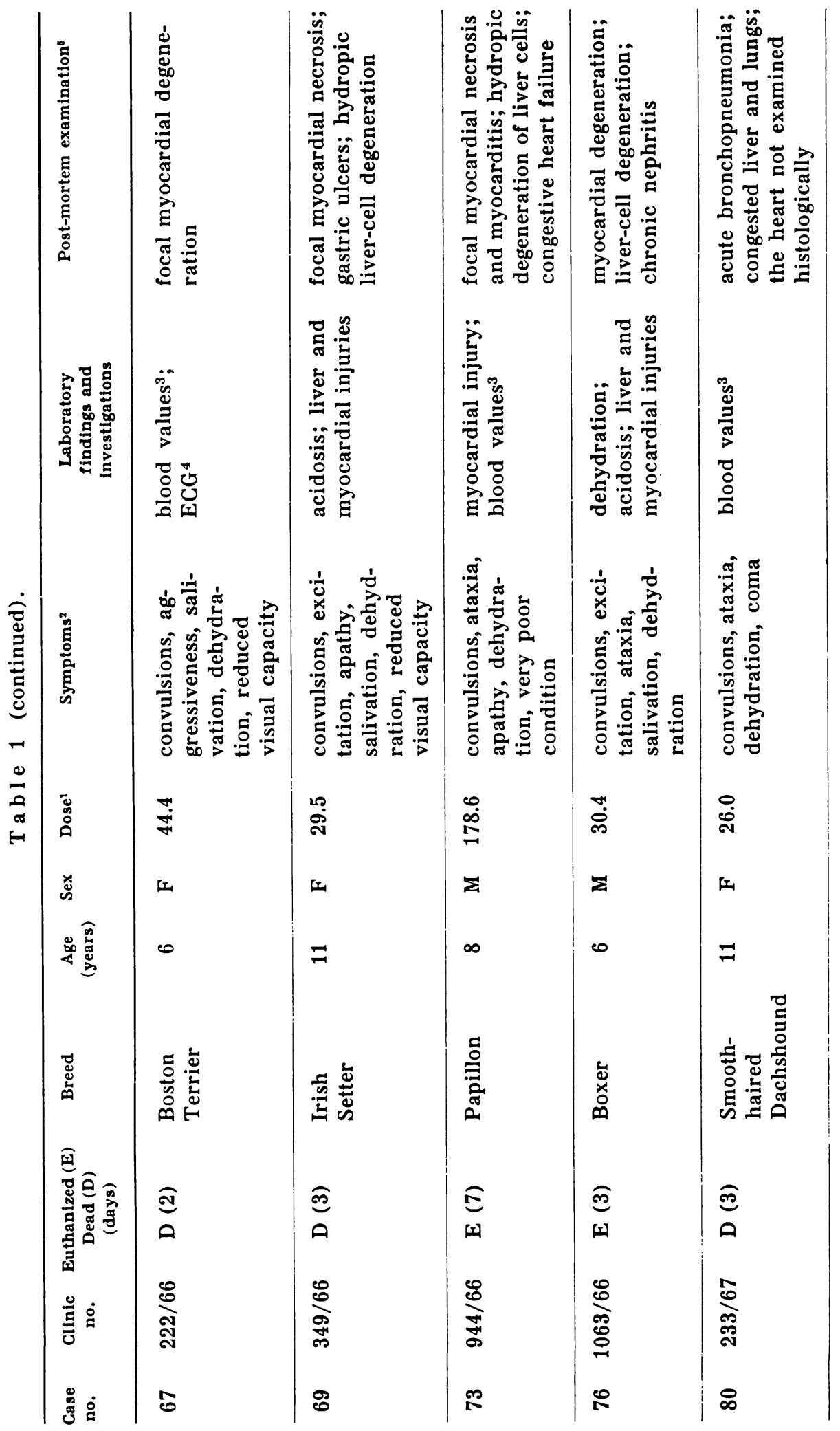




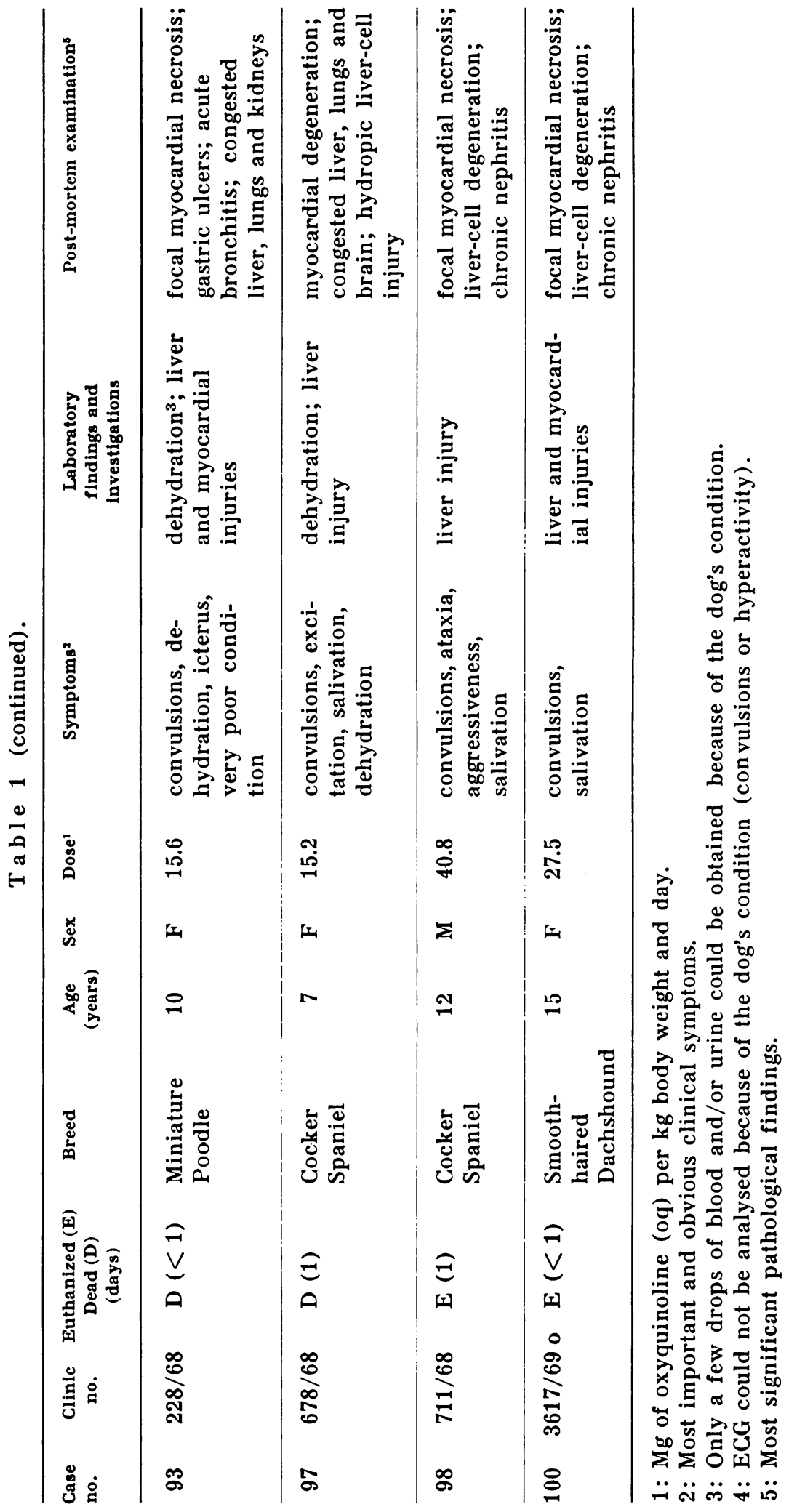


were present in 1 dog, but myocardial degeneration was not observed at routine necropsy. In another case the heart was not examined microscopically.

The myocardial damage varied greatly from one dog to another. Only a few scattered foci of degenerating muscle fibres or necrosis were found in some, whereas in others there were multiple foci of myocardial damage. The foci were observed in all ventricular and sometimes in the atrial walls but were most frequent in the papillary muscles of the left ventricle.

The myocardial injury in cases of early-stage poisoning consisted of homogenization and granular disintegration of the muscle fibres. Myocardial necrosis had developed in dogs which had had symptoms for some days.

Some necrotic lesions consisted of only a few muscle cells, while others were several $\mathrm{mm}$ in diameter. They were numerous and often confluent. Infiltration of neutrophilic leukocytes was usual (Fig. 1). In the cases in which necropsy was performed after more than a few days of disease proliferation of histiocytes

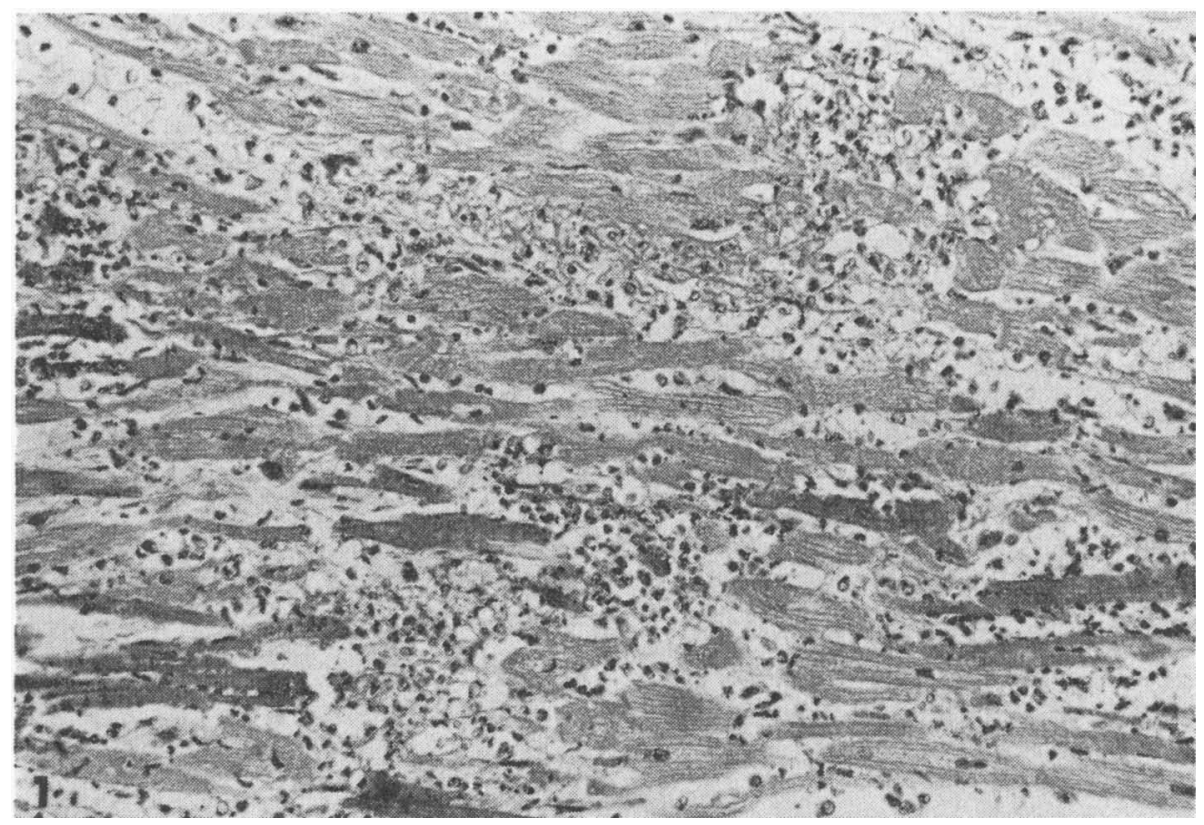

F i g u re 1. Myocardium from case no. 7 in Table 1. Several foci of degenerating muscle fibres and necrosis are observed. Interstitial oedema, infiltration of leukocytes, and proliferation of mononuclear cells are evident. Haematoxylin-eosin, $\times 130$. 
and fibroblasts was conspicuous. Stain for fat revealed numerous small fat droplets in the degenerated cells as well as in many of the surrounding muscle cells, which still retained normal crossstriation.

Cloudy swelling and hydropic degeneration of the hepatic cells were seen in 12 cases. In most cases the greater parts of the lobules were damaged. The hepatic cells were ballooned and of varying size and shape. The cytoplasm appeared granulated in some cases and vacuolated in others. Some vacuoles did not contain fat or glycogen, while others were laden with fat (Fig. 2). In cases with severe liver cell damage nuclear changes in the form of pycnosis, karyorrhexis, and karyolysis were observed. Fat deposits were sometimes found in the Kupffer cells.

\section{EXPERIMENTAL CASES}

Since oxyquinoline poisoning in dogs does not seem to be only a matter of over-dosage (Lannek 1973, 1974) and since the

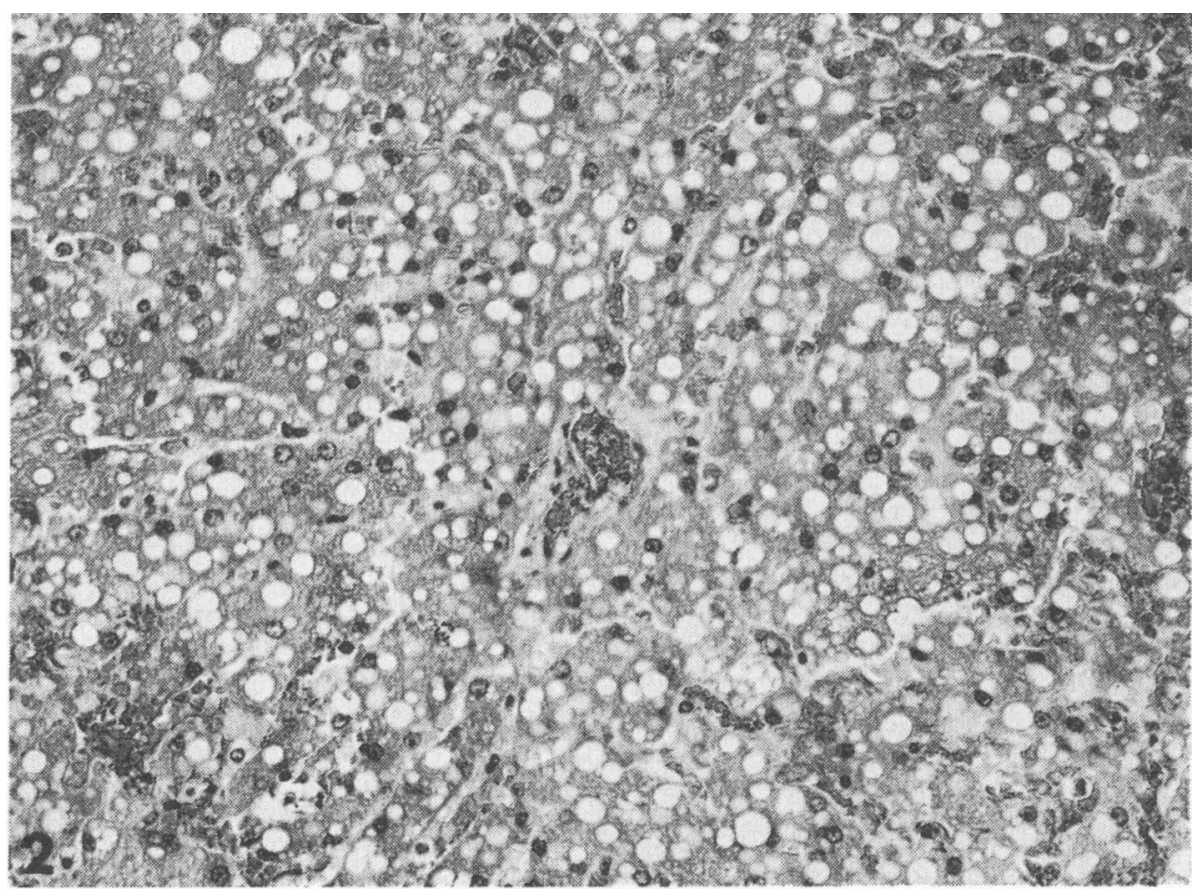

F i g u r e 2. Liver from case no. 54 in Table 1. The cytoplasm of the hepatic cells is vacuolated. Some of the vacuoles contain lipids. There is loss of some liver-cell nuclei and others are pycnotic. Haematoxylineosin, $\times 210$. 
drug is normally tolerated without any apparent diseased condition, trials have been made to reproduce a state of oxyquinoline poisoning. Experiments were designed to produce intoxication after short-term or long-term administration of vioform under various conditions, and also to study the absorption, distribution, and elimination of the drug. For the latter purpose, radioactive vioform was used. Detailed descriptions of these experiments have been given by Lannek \& Lindberg $(1974$ a, b).

As spontaneous oxyquinoline poisoning occurs only sporadically in dogs, it could be expected that trials to produce intoxication would only rarely be successful. A large number of experiments have been performed, including about 80 individual dogs (a few dogs were used several times). Of these, 34 dogs fell ill and the outcome was fatal in 7 cases. Three dogs died spontaneously and 4 had to be killed because of their diseased condition; necropsy was performed in all these cases.

\section{Methods}

Routine necropsies were performed in 4 cases. Microscopical examination was made of liver, kidneys, myocardium, lungs, and brain. The brain of $1 \mathrm{dog}$ (Sl.) was not examined. In 2 other cases necropsy was performed immediately after euthanasia and all organs were examined microscopically.

To obtain rapid fixation, especially of the central nervous system, retrograde aortic perfusion of the fixation medium was used in 1 case. With the dog under barbiturate anaesthesia, the aorta was cannulated caudal to the origin of the renal arteries. Both jugular veins were opened. After retrograde flushing through the aorta with 51 of Ringer's solution at $120-150 \mathrm{~mm}$ $\mathrm{Hg}, 10 \%$ neutral formalin was perfused at the same pressure. The fixation medium, $6 \mathrm{l}$, was perfused through the dog until the return through the jugular veins consisted purely of fixative. About 7-8 min. were required for perfusion with Ringer's solution and formalin. The dog maintained cardiac and respiratory movements until actual fixation began. Fixation by this technique resulted in blood-free organs and tissues cranial to the lumbar aorta.

Blocks for microscopical examination were taken from all organs. The brain was sectioned transversely at intervals of $3 \mathrm{~mm}$ from the olfactory lobe to the medulla oblongata. Blocks were then taken from various parts of these slab sections. 


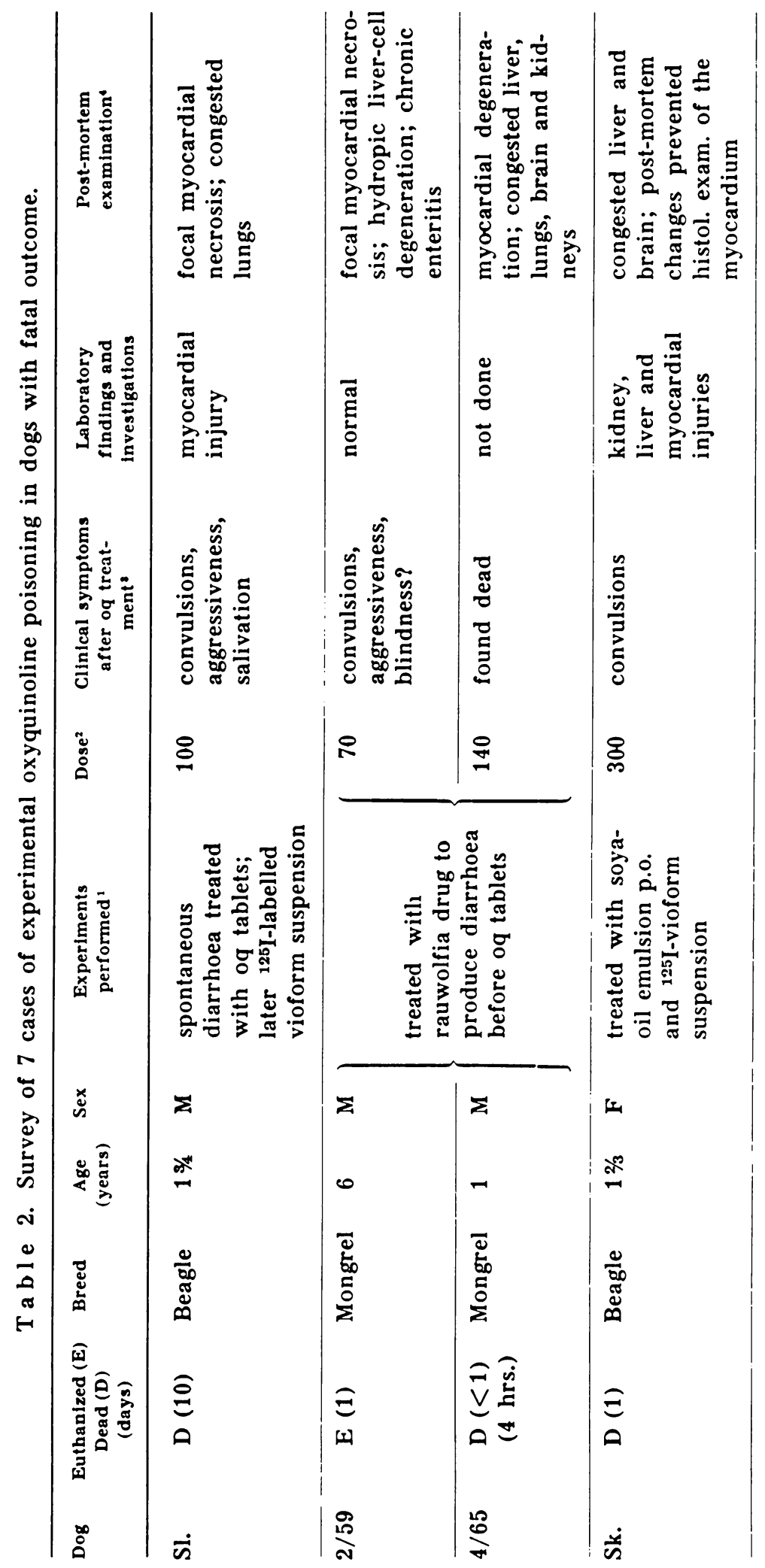




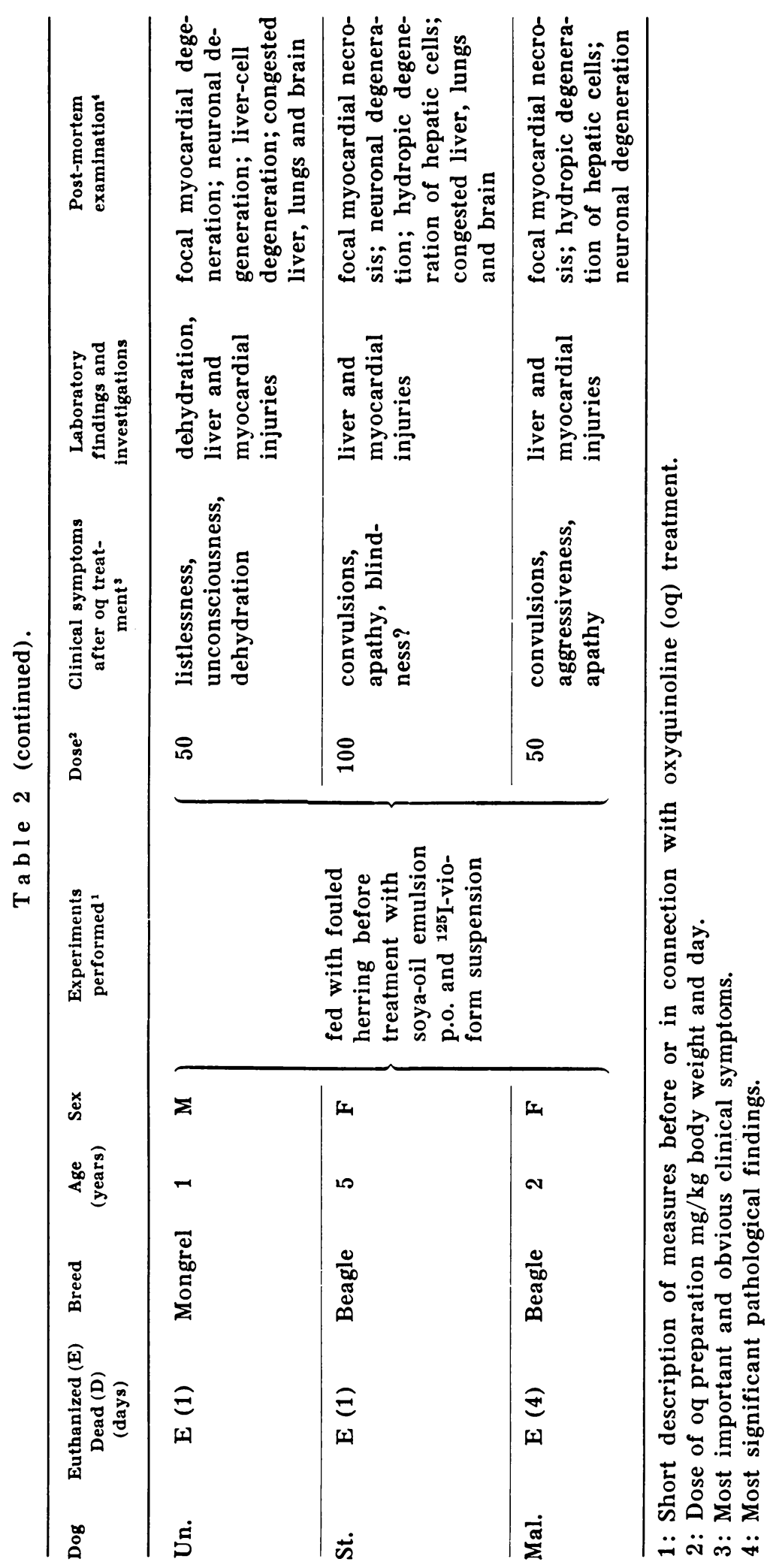


Paraffin sections of blocks from the various tissues were stained with haematoxylin-eosin, van Gieson's method, phosphotungstic acid haematoxylin (PTAH), acid fuchsin, Masson's trichrome, and Goldner's modification of that stain. The nervous tissue was stained with haematoxylin-eosin, luxol fast blue, cresyl echt violet (CEV), and gallocyanin-chrome alum (Marshall $\&$ Horobin 1972). Frozen sections from liver, kidneys, and myocardium were stained with Scharlach $\mathbf{R}$.

\section{Results}

Data on the cases of experimental oxyquinoline poisoning with fatal outcome are listed in Table 2 . Besides the dogs' signalments, it includes the type of experiments which had been performed before the dogs fell ill, and the clinical, laboratory, and post-mortem findings.

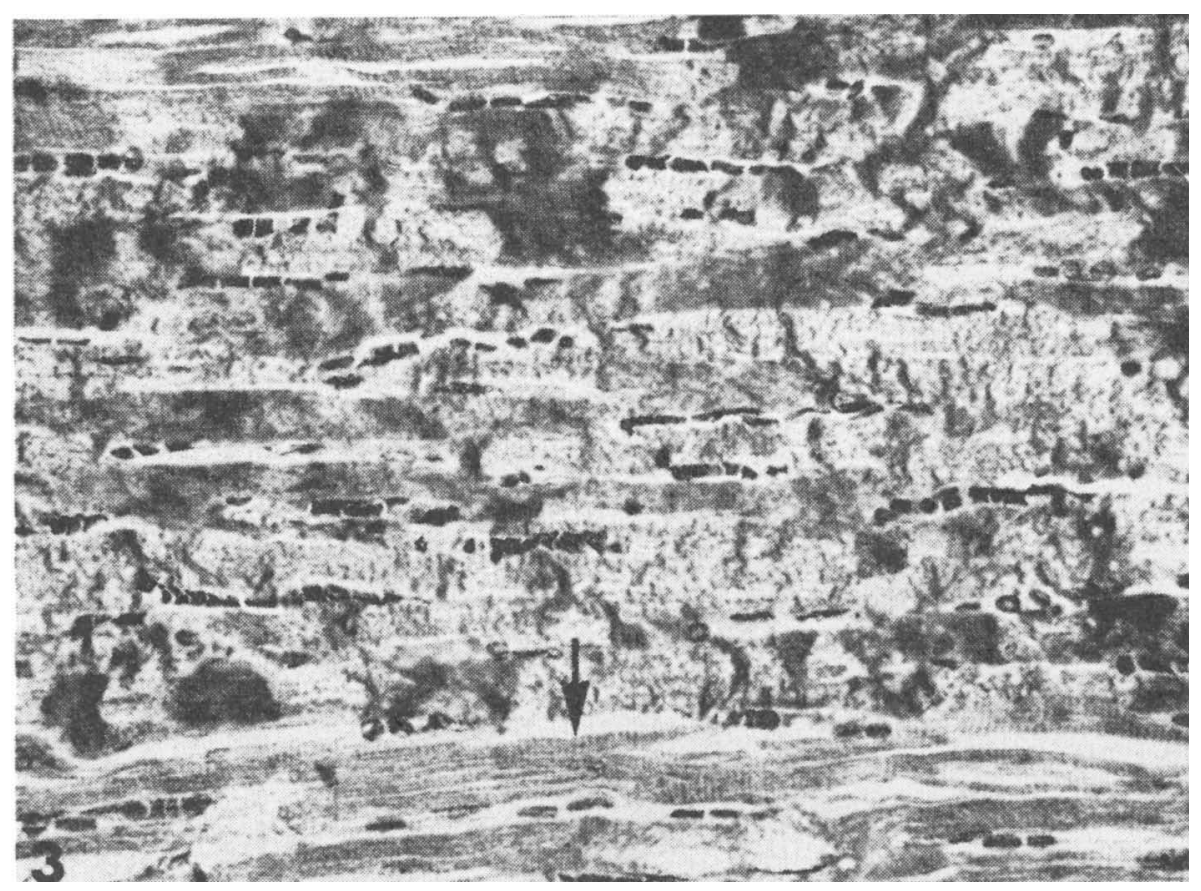

F i g u r e 3. Myocardium 1 day after administration of oxyquinoline (Sk. in Table 2). Myocardial fibres of normal striated appearance are demonstrated (arrow). The other myocardial fibres show alteration of cytoplasmic architecture with transverse bands and intervening granularity. Nuclei of interstitial cells and capillaries are seen but myocardial nuclei are not evident. Goldner's trichrome, $\times 320$. 
The main pathological changes were limited to the central nervous system, myocardium, and liver. Heart lesions were observed in 4 dogs. Multiple small subendocardial haemorrhages were seen in the left ventricle, most marked on the papillary muscles and trabeculae carneae. In 5 of the dogs, the inner part of the myocardium showed some poorly defined, sometimes confluent, brown or yellowish-brown areas on gross examination.

\section{Microscopical findings}

On microscopical examination, 6 hearts showed focal myocardial degeneration and necrosis (Fig. 3). In 1 case, postmortem changes were too severe for histological examination. Although seen anywhere in the wall of the left ventricle, the damaged muscle cells were most prominent in the inner third

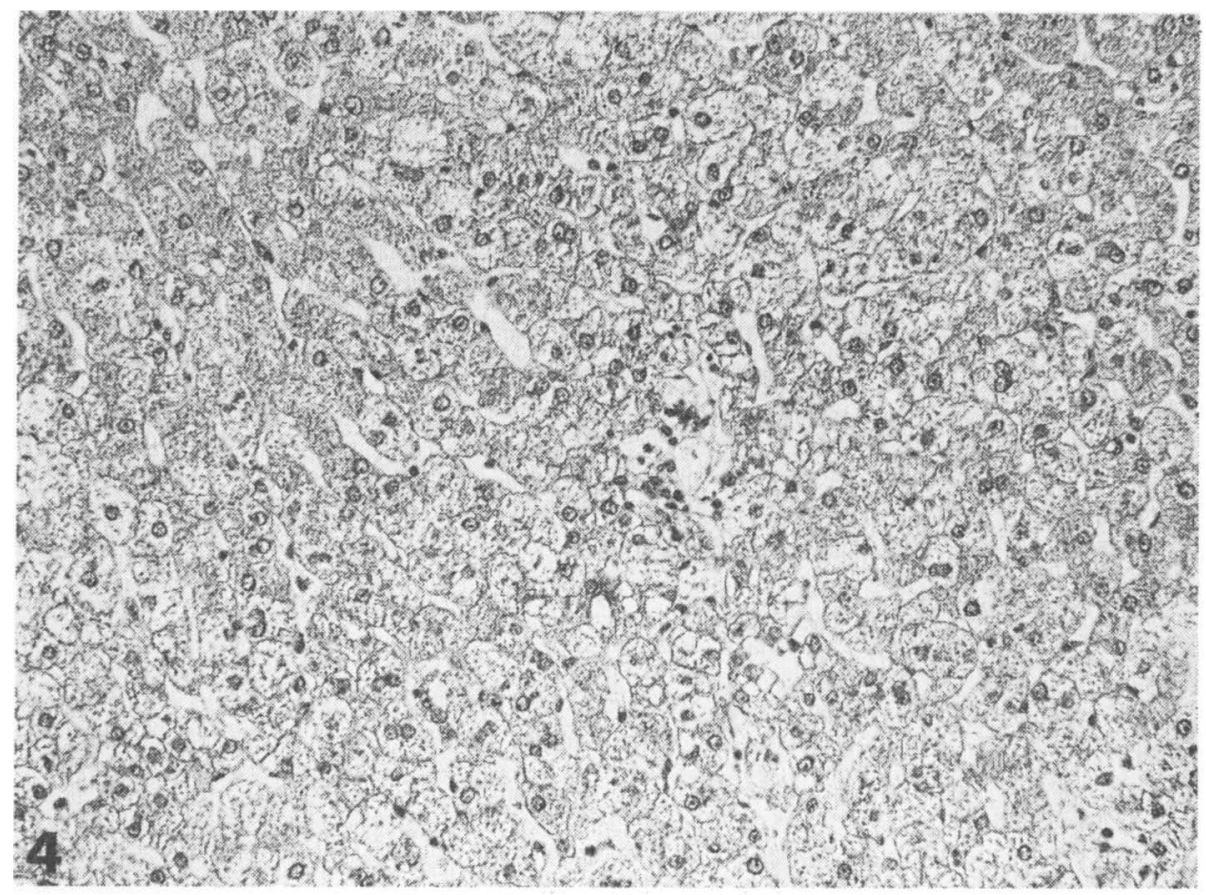

Figure 4. Liver 4 days after administration of oxyquinoline (Mal. in Table 2). The arrangement of the hepatic cells is disorderly. The cells are ballooned and vary greatly in size and shape. The cytoplasm is finely granulated and vacuolated. The staining quality of the nuclei also varies. Fixation by retrograde aortic perfusion of the fixation medium. Haematoxylin-eosin, $\times 175$. 
of the wall, particularly in the papillary muscles. Lesions were also found everywhere in the right ventricle. Only minimal changes were noted in the atria.

In 4 cases there was liver-cell degeneration, and in 1 case this cell damage was combined with fat deposits. The liver cells were ballooned and of varying size and shape. The cytoplasm was finely granulated and vacuolated (Fig. 4). Congestion was mostly found in liver, lungs, and kidneys.

Severe cellular changes were seen in the central nervous system of 3 dogs. Neuron changes were predominantly of ischaemic type, i.e. shrinkage, loss of cytoplasmic detail with increased affinity for basic stains, and nuclear pycnosis. The pyramidal cells of the cornu ammonis showed extensive degeneration and also focal necrosis (Figs. 5, 6). Sporadic similar neuron changes were seen in nucleus amygdalae.

In the thalamus and hypothalamus, the neuron damage was extensive. Almost all of the neurons of the main hypothalamic nuclei showed degenerative changes of great variety and differing intensity (Fig. 7). Some neurons showed swelling of the cytoplasm with chromatolysis and occasional vacuolation. Other nerve cells were shrunken, still others were reduced to shadows or had undergone complete dissolution resulting in a cell loss. The superior colliculi and the red nucleus showed neuronal regressive changes of moderate to severe grade. The nuclei cuneatus and gracilis showed similar changes. Slight destructive changes were also observed in the substantia nigra and in the reticular formation of the pons and the medulla. Neuron degeneration was also seen in the dorsal horns of the spinal cord. No changes were

Figure 5. Hippocampus (cornu ammonis) 4 days after administration of oxyquinoline (Mal. in Table 2). Severe degeneration and loss of nerve cells in all layers of the cornu ammonis. Two areas of focal loss of nerve cells are demonstrated (arrows). Fixation by perfusion technique. Cresyl echt violet (CEV), $\times 25$.

F ig u re 6. Higher power of section depicted in Fig. 5. Focal loss of nerve cells are demonstrated (arrows). Remaining nerve cells are shrunken with pycnotic nuclei. CEV, $\times 62$.

Figure 7. Hypothalamus 4 days after administration of oxyquinoline (Mal. in Table 2). Four neurons show swelling of the cytoplasm with chromatolysis and vacuolation. CEV, $\times 700$. 

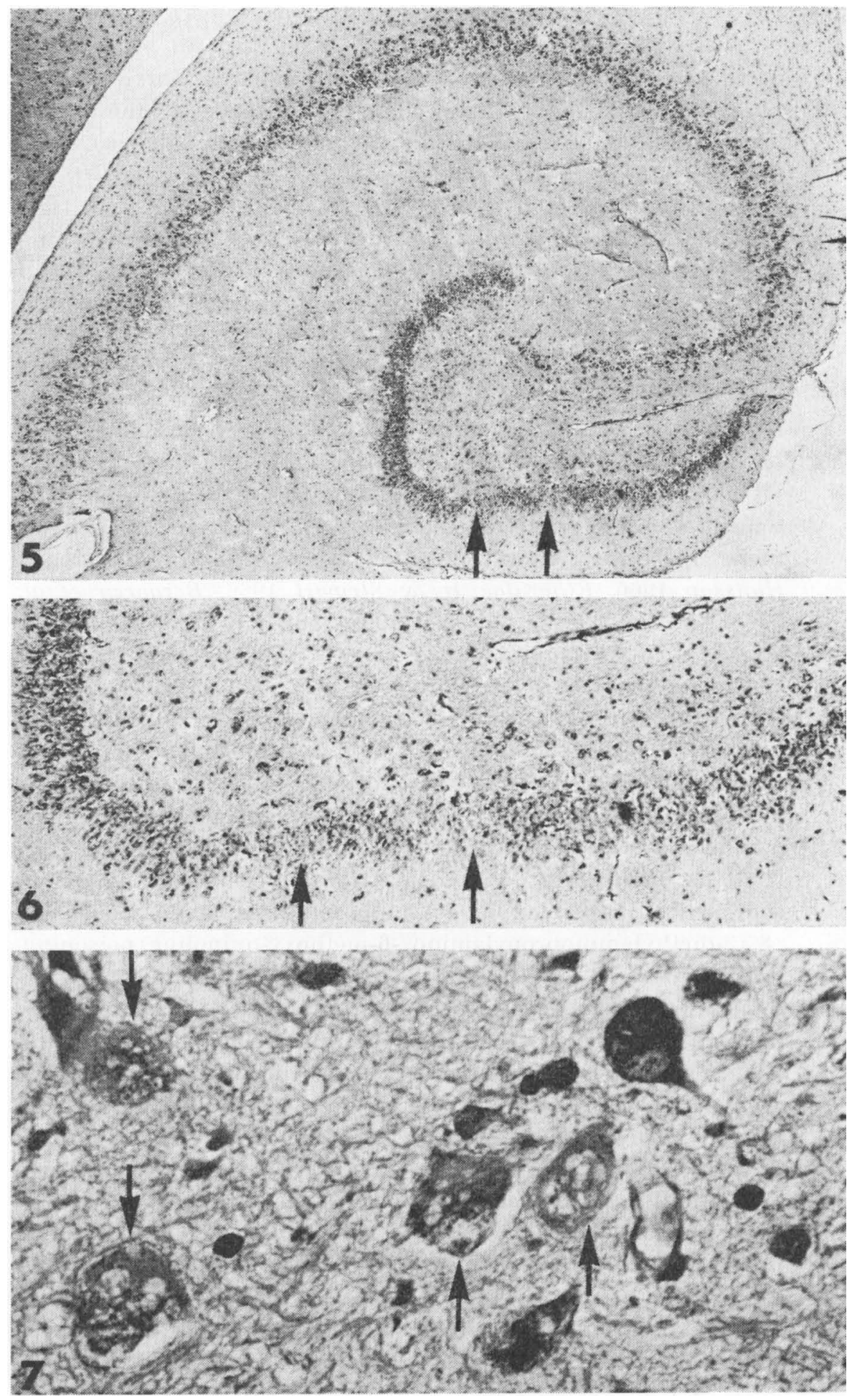
noted in the optic tract, cerebellum, or peripheral nerves. It was remarkable that the neuronal changes in all parts of the central nervous system lacked cellular reaction (neuronophagia).

\section{DISCUSSION}

The present investigation revealed that both spontaneous and experimental poisonings with halogenated oxyquinolines result in development of severe cardiac lesions characterized by focal necrosis. Liver-cell damage was observed in most of the spontaneous and experimental cases. It was also shown that degenerative changes of the central nervous system occur. Only a few reports concerning the pathological lesions at poisoning with oxyquinolines have been published.

The greatest interest has been focused on the clinical symptoms due to the toxic effect on the central nervous system. Thus, there are several reports on optical-nerve atrophy (Berggren \& Hansson 1966, Etheridge Jr. \& Stewart 1966, Berggren et al. 1968, Strandvik \& Zetterström 1968) and on other neuro-toxic effects such as amnesia (Kaeser \& Wüthrich 1970, Kaeser \& Scollo-Lavizarri 1970, Kjaersgaard 1971, Bengtsson \& Vikrot 1972) after oxyquinoline therapy. Only in 2 clinical works (Hangartner 1965, and Schantz \& Wikström 1965) it is mentioned that myocardial and liver injuries occur in oxyquinoline poisoning. Griffith (1969) mentions liver damages in an experimental work about broxyquinoline (Intestopan).

It is interesting to compare the myocardial changes in the present investigation with those observed in plasmocid (8-/3-diethylaminopropylamino/-6-methoxy-quinoline) poisoning. Plasmocid is an efficacious antimalarial agent that has serious toxic side effects, especially on skeletal muscle, heart, and the nervous system. It has been demonstrated that a single subcutaneous or intraperitoneal injection of plasmocid in rats $(2-3 \mathrm{mg}$ ) regularly produces focal myocardial necrosis associated with cellular inflammatory reaction (Bajusz et al. 1964, Bajusz \& Jasmin 1965). Histological sections revealed rather extensive myocardial damage, especially in the subendocardial layers of both ventricles. The occurrence of necrotic foci was not restricted to this region but often involved the whole ventricular wall and the interventricular septum. The myocardial lesions in these 2 studies were similar to those observed in the present investigation. Ultrastructural changes in cardiac and skeletal muscle 
induced by plasmocid were studied by d'Agostino in 1963. In the myocardium the earliest changes were confined to the mitochondria and only later did they involve myofilaments.

In oxyquinoline poisoning, spontaneous or experimental, the myocardial injury was often severe. Some agreement between the CNS symptoms and the myocardial damage cannot be excluded. In all the cases, symptoms referable to the CNS appeared. The dogs that had the most violent convulsions had also an electrocardiographic picture indicating extensive myocardial damage. Convulsions and severe myocardial damage have been observed in 3 dogs, which had not been treated with oxyquinolines and in which necropsy showed no CNS abnormalities (Lannek, personal observation). Redding (1969) mentions that clinical seizures associated with cardiac disease have been reported. In these cases the heart was supposed to be an inefficient pump with resulting hypoxia of the brain. However, a lowered oxygen tension in the blood may cause a variety of signs, the most common one being syncope. This symptom has never been observed in oxyquinoline poisoning, and the symptoms indicating CNS injury are probably not caused by the cardiac insufficiency.

The severity and distribution of liver-cell damage varied. The lesions ranged from swollen hepatocytes to hydropic degeneration with, in some cases, fat deposits. These types of liver injuries are unspecific and occur in many conditions, for instance in infections and intoxications. The biopsy specimens showed diffuse fat deposition and/or evidence of circulatory changes in 17 out of 18 cases. One specimen showed the picture of acute hepatitis. This dog (case no. 47) may have suffered from a slight hepatitis from the beginning, and the initial diarrhoeic condition for which the oxyquinoline treatment was started, may have been caused by the hepatitis. However, at necropsy, which was performed the day after the specimen was taken, no signs of acute hepatitis were found. The biopsy specimen may have been inadequate for correct estimation.

Evaluation of the CNS lesions was possible in only 3 experimental cases. In the spontaneous cases and in 4 of the experimental cases necropsy was performed more than $5 \mathrm{hrs}$. after death. Therefore the structural changes in the nerve cells could not be evaluated in these cases.

Morphological examination of the hippocampus showed extensive nerve-cell degeneration. 'This observation was in agreement 
with experimental findings in mice, dogs, and cats (Püschner \& Fankhauser 1969). They found that the hippocampus was a predilection site. In the present investigation, however, nerve-cell degeneration was also noted in other parts of the CNS, for example in the thalamus and hypothalamus.

This widespread localization of nerve-cell degeneration was observed in experimental studies with plasmocid (Schmidt \& Schmidt 1949, 1951, Richter 1949). There is some variation in the results of experimental studies with oxyquinolines. Schneider \& Coper (1968) produced diffuse lesions in the grey matter of the spinal cord in rats after administration of heavy doses of 5-nitro-8-hydroxychinoline ( $500 \mathrm{mg}$ per day for 14 days). Lesions of the cerebrum, cerebellum, and brain stem were apparently not observed.

Some Japanese investigators are of the opinion that the subacute myelo-optic neuropathy (S.M.O.N.) in Japan (Tsubaki et al. 1971, Igata 1971, Nakae et al. 1971, Tateishi et al. 1971) is caused by oxyquinolines. Tateishi et al. in experiments on dogs with chronic poisoning, observed degenerative changes in the fasciculus gracilis of the spinal cord and the optical tract. The lesions consisted of advanced nerve-cell degeneration, accompanied by distinct demyelination and accumulation of fat granules. The difference between the histopathological changes in the present investigation and those observed by other investigators may be due to different duration of exposure to the drug.

The observation that the hippocampus seems to be a predilection site is of interest. There are reports of amnesia in man after short-term treatment with oxyquinoline derivatives (Kaeser \& Wüthrich, Kaeser \& Scollo-Lavizarri, Kjaersgaard, Bengtsson \& Vikrot). The hippocampus is of central importance for the memory (Drachman \& Arbit 1966). To confirm that a dog suffers from loss of memory (amnesia) is difficult, unless one knows the dog well. Most case histories tell about a change in the dogs' temperament or behaviour. The dog often seems to be disoriented and has an absent or anxious expression. This is in agreement with the author's (B.L.) experience from the experimental cases, and these symptoms may be interpreted as signs of amnesia.

Several dogs showed aggressiveness (Tables 1 and 2), which sometimes made them difficult to handle. It is now believed that the hippocampus plays the role of correlating sensory information and sending it to the hypothalamus and other centres of atten- 
tion and learning (Hoerlein 1971, page 49). The functions of the hypothalamus are many and diversified. Lesions of this structure may produce a variety of signs including wakefulness patterns and changes in the sleep. Personality changes manifested by fear and rage have been produced by experimental destruction of the pathways from the cerebral cortex (Hoerlein). In 3 experimental cases, Un., St., and Mal., especially in the latter one, in which the retrograde perfusion technique was used, rapid fixation of the CNS was attained. These dogs showed severe clinical symptoms (see Table 2 and Lannek \& Lindberg 1974 a), and the postmortem examination of the CNS revealed extensive damages in the cornu ammonis and in the thalamus and hypothalamus. According to Hoerlein (1971, page 49), "the ventromedial nuclei of hypothalamus are believed to be responsible for tameness and emotional stability. When this area is destroyed, animals which were previously tame display varying degrees of wildness and savageness. They will attempt to escape, will growl, and may attack savagely if approached". This is in agreement with the dog Mal.'s symptoms. Destruction of the posterior hypothalamus results in general stolidity and inactivity, with a tendency to sleep most of the time. Many of the experimental dogs that fell ill after oxyquinoline therapy showed obvious tiredness or listlessness. This was most prominent in the dog Un., which was used several times. He was very sleepy on each occasion, the last time listless to comatose. In many of the spontaneous cases the dogs also showed listlessness to apathy.

Since 1966 there have been some reports about optical-nerve atrophy in man (Berggren \& Hansson, Etheridge Jr. \& Stewart, Berggren et al., Strandvik \& Zetterström). In these cases the patients had suffered from acrodermatitis enteropathica. Oxyquinolines are the drugs of choice, and the patients had been treated with extremely high doses of an oxyquinoline drug and over long periods. Some of the experimental dogs that fell ill after short-term treatment with oxyquinolines behaved as if they were blind or had impaired vision. This had also been noticed by the owners to some of the spontaneous cases. But no changes were found in the optical nerve at necropsy.

The clinical symptoms of neurological disturbances, for instance tremor and convulsions, may have several causes. They may be a result of direct toxic effect on the CNS and/or caused by hepatic lesions. Hepatocerebral intoxication is a syndrome 
characterized by progressive mental changes, deterioration and fluctuation in the stage of consciousness, and finally coma (Hoerlein 1971, page 480). When there is a marked decrease in the amount of functioning liver parenchyma, as is seen at hydropic degeneration and necrosis of the liver cells, a clinical syndrome known as hepatic encephalopathy develops. The amount of free ammonia in the blood rises, as a result of bacterial degradation of protein in the gastrointestinal tract, and enters the cells of the central nervous system (Slahl 1963). However, the clinical symptoms of neurological disturbances in oxyquinoline poisoning, such as convulsions, apathy, nervousness, etc, are probably due to toxic effects of the drug directly on the CNS. In some cases the analyses of cerebrospinal fluid (12 cases) showed changes probably due to toxic substances, which had damaged the brain tissue or caused increased capillary permeability (Lannek 1974). According to the aetiological classification by Redding, the neurological disturbances in the present cases would belong to the group of acquired seizures caused by damage of the brain tissue in metabolic disorders or by chemical intoxication.

The injuries in the CNS, liver, and myocardium and the circulatory disturbances were the most prominent clinical and postmortem findings (Tables 1 and 2). Besides, in some cases there were acute bronchopneumonia, chronic nephritis, and gastric erosions and ulcerations. The 2 dogs (cases nos. 31 and 80 ) which had an acute bronchopneumonia were old dogs (12 and 11 years of age, respectively) and were in a very poor condition. Case no. 31 had focal myocarditis, but in no. 80 the heart, unfortunately, was not examined histologically. Acute bronchopneumonia is a rather common complication and is not seldom the cause of death, especially in older patients. Chronic nephritis was found in 4 cases. This condition is common in old dogs and is often asymptomatic in an early stage. It has been shown that old dogs were affected by oxyquinoline poisoning more often than young dogs and also showed higher mortality (Lannek 1973). Chronic nephritis is probably an accessory finding in those cases. Acute gastric erosions and ulcerations were found in the fundus region in 6 cases; in none were the ulcers perforating or bleeding. The erosions and ulcerations in the present material probably indicate acute gastritis or perhaps uraemic gastritis. None of the dogs with gastric ulcers had any clinical or post-mortem signs of chronic nephritis or uraemia, however. 
The question whether these changes in the gastric mucosa, as well as the initial enteritis, are of any significance in the absorption of oxyquinolines cannot be answered. In 98 out of 100 cases of spontaneous oxyquinoline poisoning the dogs suffered from acute mild enteritis, but according to the experiments performed, the diarrhoeic condition is not of any significance (Lannek \& Lindberg 1972 a, b, 1974 a, b). Nor are there any reports of initial enteritis in cases of amnesia in man after oxyquinoline treatment. On the other hand, the condition called S.M.O.N. (subacute myelo-optic neuropathy), which has recently been described from Japan, starts with abdominal disorders followed by sensory-motor disturbances after oxyquinoline treatment (Sobue et al. 1971, Annotation Lancet 1971, Bengtsson \& Vikrot). Thus, this syndrome seems to be rather like the intoxication in dogs after an initial abdominal disorder. In accordance with the Lancet (Annotation 1971, page 1244) "Perhaps a virus is the underlying cause of the gastro-intestinal upset for which clioquinol is taken or perhaps the abdominal condition allows increased absorption and causes sensitivity to clioquinol", it must be suspected that the enteritis and/or some other factor (e.g. fat) is responsible for an increased absorption in some cases.

\section{REFERENCES}

Annotation: More on S.M.O.N Lancet 1971, 2, 1244.

Bajusz, E. \& G. Jasmin: Enzyme histochemistry of some chemically induced cardiac necroses. I. Myocardial lesions induced by plasmocid. II. Vitamin-, Hormon- und Fermentforsch. 1965, 14, 28-42.

Bajusz, E., G. Jasmin \& A. Mongeau: Dissociation by forced muscular exercise of the cardiotoxic from the myotoxic actions of plasmocid. Rev. canad. Biol. 1964, 23, 29-36.

Bengtsson, K. \& O. Vikrot: Retrograd amnesi efter broxikinolin. (Retrograde amnesia after broxyquinoline). Svenska Läk.-Tidn. $1972,69,14-16$.

Berggren, L. \& O. Hansson: Treating acrodermatitis enteropathica. Lancet $1966,1,52$.

Berggren, L., O. Hansson \& I. Wahlberg: Läkemedelsbiverkan och tarmresorbtion av 8-hydroxikinolinpreparat. (Secondary effect and absorption from the intestine of 8-hydroxyquinoline drugs). Svenska Läk.-Tidn. 1968, 65, 3772—3773.

D'Agostino, A. N.: An electron microscopic study of skeletal and cardiac muscle of the rat poisoned by plasmocid. Lab. Invest. 1963, $12,1060-1071$. 
Drachman, D. A. \& J. Arbit: Memory and the hippocampal complex. Arch. Neurol. (Chic.) 1966, 15, 52-61.

Etheridge, J. E., Jr. \& G. T. Stewart: Treating acrodermatitis enteropathica. Lancet $1966,1,261-262$.

Griffith, $R$. W.: Intestopan, a 26-week oral toxicity study in dogs. Sandoz Ltd., Dept. Pharm. Tox., March 28/1969 (unpublished).

Hangartner, P.: Troubles nerveux observés chez le chien après absorption d'Entéro-Vioforme Ciba. (Nervous symptoms observed in dogs after absorption of Enterovioform Ciba). Schweiz. Arch. Tierheilk. 1965, 107, 43-47.

Hoerlein, B. F.: Canine Neurology - Diagnosis and Treatment. 2nd Ed., W. B. Saunders Company, Philadelphia 1971.

Igata, A.: Comments. Lancet 1971, 2, 42-43.

Kaeser, H. E. \& G. Scollo-Lavizzari: Akute zerebrale Stðrungen nach hohen Dosen eines Oxychinolinderivates. (Acute cerebral disturbance after high doses of an oxyquinoline derivative). Dtsch. med. Wschr. 1970, 95, 394-397.

Kaeser, H. E. \& R. Wüthrich: Zur Frage der Neurotoxizität der Oxychinoline. (On the possible neurotoxicity of oxyquinoline). Dtsch. med. Wschr. 1970, 95, 1685—1688.

Kjaersgaard, K.: Amnesia after clioquinol. Lancet 1971, 2, 1086.

Lannek, B.: Leverbiopsi hos hund. Ett diagnostiskt hjälpmedel. (Liver biopsy in dogs. A diagnostic aid). Svensk Vet.-Tidn. 1968, 21, $591-594$.

Lannek, B.: Toxicity of halogenated oxyquinolines in dogs. A clinical study. I. A survey of cases. Acta vet. scand. 1973, 14, 723-744.

Lannek, B.: Toxicity of halogenated oxyquinolines in dogs. A clinical study. II. History, symptoms, laboratory findings, therapy, and follow-up. Acta vet. scand. 1974, 15, 219-238.

Lannek, B.\& P. Lindberg: Vioform poisoning in dogs. The absorption of vioform from the intestine. Svensk Vet.-Tidn. $1972 \mathrm{a}, 11$, $438-441$.

Lannek, B. \& P. Lindberg: Toxicity of halogenated oxyquinolines to dogs. The effect of feeding fouled herring. Acta vet. scand. 1972 b, 13, 441-442.

Lannek, B. \& P. Lindberg: Toxicity of halogenated oxyquinolines in dogs. A clinical study. III. Intoxication experiments. Acta vet. scand. 1974 a, $15,398-418$.

Lannek, B. \& P. Lindberg: Toxicity of halogenated oxyquinolines in dogs. A clinical study. IV. Tissue distribution and elimination in urine. Acta vet. scand. $1974 \mathrm{~b}, 15,419-435$.

Marshall, P. N.\& R. W. Horobin: The chemical nature of the gallocyanin-chrome alum staining complex. Stain Technol. 1972, 47, $155-161$.

Müller, L. F.: Die Mexaformvergiftung des Hundes (Klinische Demonstration). (The mexaform poisoning in the dog. Clinical demonstration). Kleintier-Prax. 1967, 12, 51-52.

Nakae, K., S. Yamamoto \& A. Igata: Subacute myelo-opticoneuropathy (S.M.O.N.) in Japan. Lancet 1971, 2, 510-512. 
Poley, R. W., L. C. D. Fobes \& M. J. Hall: Fuchsinophilia in early myocardial infarction. Arch. Path. 1964, 77, 325-329.

Püschner, H. \& R. Fankhauser: Neuropathologische Befunde bei experimenteller Vioform-Vergiftung der weissen Maus. (Neurological symptoms after experimental Vioform poisoning in the white mouse). Schweiz. Arch. Tierheilk. 1969, 111, 371-379.

Redding, $R$. W.: Diagnosis and therapy of seizures. J. Animal Hosp. Ass. $1969,5,79-92$.

Richter, R.: The effect of certain quinoline compounds upon the nervous system of monkeys. J. Neuropath. exp. Neurol. 1949, 8, $155-170$.

Schantz, B. \& B. Wikström: Suspected poisoning with oxyquinoline preparations in dogs. Svensk Vet.-Tidn. 1965, 4, 106-107.

Schmidt, I. G. \& L. H. Schmidt: Neurotoxicity of the 8-aminoquinolines. II. Reactions of various experimental animals to plasmocid. J. comp. Neurol. 1949, 91, 337-351.

Schmidt, I. G. \& L. H. Schmidt: Neurotoxicity of the 8-amino-quinolines. III. The effects of pentaquine, isopentaquine, primaquine and pamaquine on the central nervous system of the rhesus monkey. J. Neuropath. exp. Neurol. 1951, 10, 231-256.

Schneider, H.\&H. Coper: Morphologische Befunde am Zentralnervensystem der Ratte nach Vergiftung mit Antimetaboliten den Nicotinamids (6-aminonicotinsäureamid und 3-acetylpyridin) und einem Chinolinderivat (5-nitro-8-hydroxychinolin). (Morphologic findings in the central nervous system of the rat at poisoning by antimetabolites of the nicotine amids and quinoline derivatives). Arch. Psychiat. Nervenkr. 1968, 211, 138-154.

Sobue, I., K. Ando, M. Iida, T. Takayanagi, Y. Yamamura \& Y. Matsuoka: Myeloneuropathy with abdominal disorders in Japan. Neurology (Bombay) 1971, 21, 168-173.

Stahl, J.: Studies on the blood ammonia in liver disease. Ann. intern. Med 1963, 58, 1-24.

Strandvik, B. \& R. Zetterström: Amaurosis after broxyquinoline. Lancet $1968,1,922-923$.

Tateishi, J., S. Kuroda, A. Saito \& S. Otsuki: Myelo-optic neuropathy induced by clioquinol in animals. Lancet 1971, 2, 1263-1264.

Tsubaki, T., Y. Honma \& M. Hoshi: Neurological syndrome associated with clioquinol. Lancet 1971, 1, 696-697.

\section{SAMMANFATTNING}

Toxiciteten av halogenerade oxikinoliner hos hund. En klinisk studie. V. Patolog-anatomiska förändringar.

Författarna beskriver postmortala fynd hos 21 fall av akut spontan oxikinolinförgiftning hos hund efter behandling med läkemedel innehållande halogenerade oxikinolinderivat en gång eller under kort tid. Fynden överensstämmer med obduktionerna av 7 fall av experimentell oxikinolinförgiftning. Leverbiopsier har tagits i 18 fall. Föreliggande undersökning visar att en svår myokard- och leverskada utvecklas $i$ såväl spontana som experimentella fall. Myokardskadorna 
bestod av fokala nekroser med cellreaktion i interstitiet. Nekroserna var vanligast förekommande i vänster kammares papillarmuskler. Levercellskadan varierade från albuminös degeneration till hydropisk degeneration med förfettning. I 3 experimentella fall, vilka snabbfixerades, förelåg patologiska förändringar i hjärnan och ryggmärgens neuroner. Degenerativa nervförändringar med kromatolys och vakuolisering sågs främst $\mathrm{i}$ hippocampus och hypothalamus. Skador i dessa strukturer kan förmodas ge upphov till symptom, vilka överensstämmer med hundarnas kliniska bild. Symptombilden och de postmortala fynden antas bero på en direkt toxisk effekt på myokardiet, levern och centrala nervsystemet.

(Received February 18, 1974).

Reprints may be requested from: B. Lannek, Department of Medicine I, Royal Veterinary College, S-104 05 Stockholm 50, Sweden. 